\title{
Sustainable approach to tempeh industrial wastewater management in Karawang
}

\author{
Silvi Wahyu Puspawati ${ }^{1}$ and Tri Edhi Budhi Soesilo ${ }^{1 *}$ \\ ${ }^{1}$ School of Environmental Science, Universitas Indonesia, Salemba, Indonesia
}

\begin{abstract}
Tempeh is a traditional soybean product from Indonesia. It is a high-protein food whose cost per unit is cheaper than any other animal protein sources. However, processes undertaken by tempeh industries will produce waste. To produce tempeh needs a lot of water used for boiling, soaking, leaching, and peeling the soybeans. The problem is that tempeh industries have not undertaken wastewater management properly, which potentially causes the quality of tempeh industrial wastewater to exceed the prescribed quality standard, having negative impact on both the environment and the people living around those industries. This research aims to describe tempeh industrial wastewater management. It is mixedmethods research employing qualitative and quantitative methods, especially through literature review, observation, interviews, and laboratory analysis. Research findings show that the alternative waste management suitable for tempeh industries is to utilize wastewater by considering environmental, social, and economic aspects. Such utilization is carried out by making liquid organic fertilizer and biogas from a mixture of household organic waste. These research findings refer to SDGs' agenda, especially the goal no. 6 (six), i.e. to improve water quality by reducing pollution from wastewater.
\end{abstract}

\section{Introduction}

Tempeh is a traditional soybean product from Indonesia. It is a high-protein food whose cost per unit is cheaper than any other animal protein sources like meat, milk, and eggs. It has a significant role in efforts to improve nutrition for the people, especially the middle and lower classes because it is not consumed equally by all social groups but is generally served as a variation to the menu of middle- and lower-class families [1]. About $50 \%$ of Indonesian soybean consumption is used to produce tempeh, $40 \%$ for tofu, and $10 \%$ for other products (such as tauco, soy sauce, and so on) [2]. About 50\% of soybeans are used to make tempeh and $40 \%$ to make tofu [3]. In 1988, the estimated soybean consumption for tempeh was around 764,000 MT with the average per capita consumption of $6.45 \mathrm{~kg}$ and this number has increased by an average of $10 \%$ in the past five years [1]. Tempeh industries will produce waste as a result of the processes they carry out. Such waste is generated in the forms of solid and liquid ones.

\footnotetext{
* Corresponding author: soesilo@indo.net.id
} 
To make tempeh requires a lot of water used for soaking, boiling, washing, and peeling the soybeans.

The waste produced from such processes can be either liquid or solid waste. Most of the solid waste from soybean skin has been used for animal feed. But, for liquid waste from the water used to soak and boil soybeans, it remains dumped directly in the waters. The process of making tempeh is illustrated in Fig. 1.

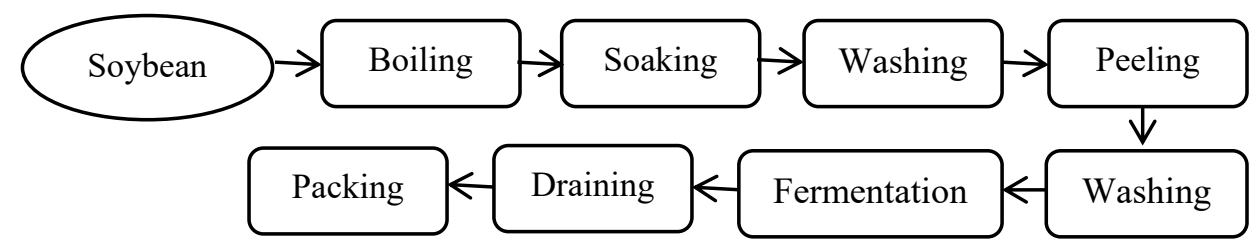

Fig. 1. The process of making tempeh.

Solid waste can be used as animal feed but untreated liquid waste is capable of emitting an odor and when discharged directly into the river will result in pollution. One hundred kilos of soybeans can produce up to $2 \mathrm{~m}^{3}$ of waste [4]. The resulting liquid waste which contains suspended and dissolved solids will undergo physical, chemical, and biological changes that produce toxic substances and create a medium for bacterial growth, including germs that cause diseases. It will change the colour of wastewater into black and produce an odor. This odor can cause respiratory diseases, and if the waste penetrates through the soil close to water wells, the water wells certainly cannot be used anymore. The waste discharged into rivers will pollute the river and if the water from the river is used, it can cause diarrhea and other diseases [4]. The effect of environmental pollution caused by industrial activities is also called environmental footprints. Every industry should work towards a zero environmental footprint by conserving, restoring, managing waste, and replacing natural resources it uses in its operations. Tempeh industries can reduce their environmental footprints through utilization of the waste they produces. To derive the maximum benefit from per unit of pollution, it is necessary to minimize activity and product footprints. The environmental footprint has become a key performance indicator in environmental management [5,6]. Resource efficiency means a small footprint per unit of product [7].

\section{Materials and method}

The method used in this research was a quantitative one. The approaches used in this research were quantitative and qualitative methods (mixed method) through literature review, observation, interviews, and laboratory analysis. The quantitative method was used to collect data on the quality of wastewater based on laboratory tests of several parameters (TSS, $\mathrm{BOD}_{5}$, and $\mathrm{COD}$ ). The qualitative methods were used to collect data through field observation at the research site, interviews, and literature review. This research was conducted in Wates, Karawang Regency, West Java Province, Indonesia because there are a total of 15 SMEs discharging their liquid waste into the waters. The research site is shown in Fig. 2. 


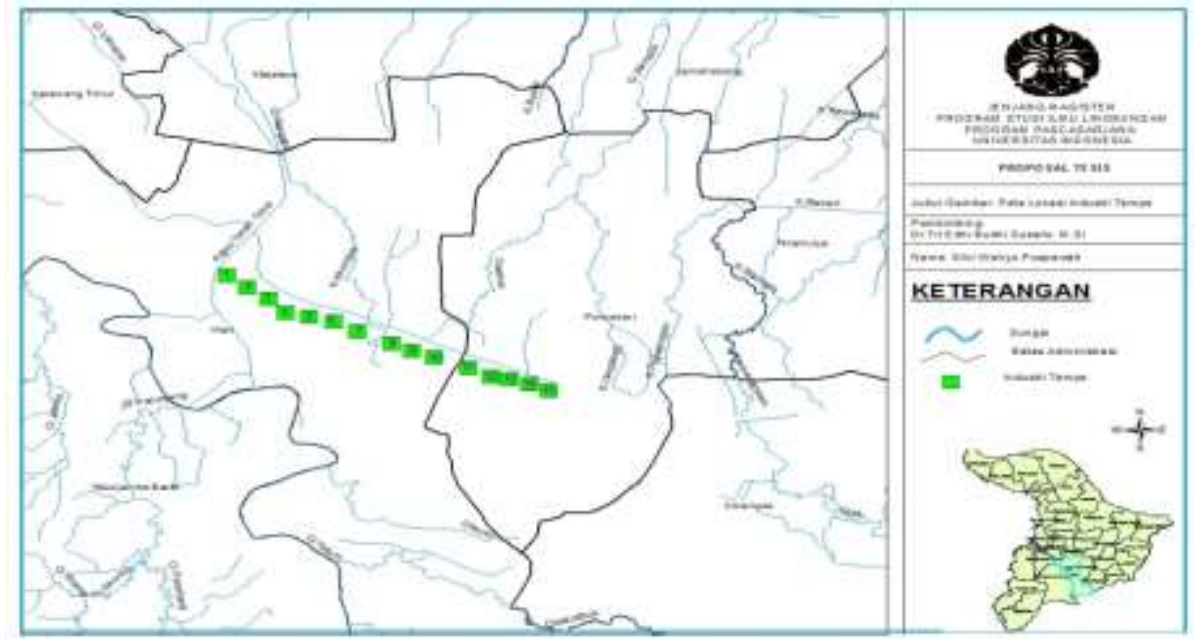

Fig. 2. Research site.

\section{Result and discussion}

Based on observation and interviews, it is revealed that the stakeholders do not manage their waste properly as they are still disposing of wastewater produced without prior processing. Small-scale tempeh industries produces wastewater of up to 1,000 liters per day. Wastewater from the water used for boiling soybeans has a high organic content and therefore they can reuse it. The wastewater produced by the tempeh industris during the production process consists mainly of water (i.e. $99.9 \%$ or more) and solid objects $(0.1 \%)$ consisting of organic and inorganic substances. During the process of soaking soybean waste, every $50 \mathrm{~kg}$ of soybeans soaked contains a quite high nitrogen content of around $1.5 \%$ of dissolved protein [8]. The levels of TSS (Total Suspended Solid), BOD (Biochemical Oxygen Demand), and COD (Chemical Oxygen Demand) of tempeh industrial wastewater are shown in Table 1.

Table 1. Concentration of tempeh industrial wastewater.

\begin{tabular}{|c|c|c|}
\hline $\begin{array}{c}\text { Wastewater } \\
\text { parameter }\end{array}$ & $\begin{array}{c}\text { Concentration of standard } \\
\text { wastewater quality }(\mathrm{mg} / \mathrm{L})\end{array}$ & $\begin{array}{c}\text { Concentration of } \\
\text { wastewater }(\mathrm{mg} / \mathrm{L})\end{array}$ \\
\hline $\mathrm{TSS}$ & 100 & 1.000 \\
\hline $\mathrm{BOD} 5$ & 150 & 14.000 \\
\hline $\mathrm{COD}$ & 300 & 27000 \\
\hline
\end{tabular}

Table 1. shows that the concentration of wastewater exceeds the prescribed waste quality standard. Therefore, the right wastewater management is required. A high TSS concentration can cause blockage of sunlight into the water. This causes the photosynthesis process to be blocked in water, resulting in a decrease in the oxygen content in the water. In the event of a reduced oxygen content because of waste, aerobic bacteria will die quickly while anaerobic bacteria will grow. It is this anaerobic activity which emits odor. High levels of TSS, BOD, and COD will kill fish and other organisms. Tempeh industrial wastewater is rich in organic compounds that can potentially be developed into a new product.

Liquid organic fertilizer is the alternative use of wastewater with a high organic content that can increase crop productivity. Organic fertilizer can be in solid and liquid forms. The 
advantage of liquid organic fertilizer is that it is easier for plants to absorb nutrients it contains [9]. Most farmers remain using inorganic fertilizer because it contains several nutrients in large quantities, but if they use is for long-term use, it will have detrimental impact on soil conditions [10].

Preparation of liquid organic fertilizer coupled with an effective inoculant or activator is used to accelerate maturity [11]. The use of Effective Microorganisms (EM4) in accelerating the manufacture of liquid fertilizer is considered a technology because it aims to accelerate the fermentation process [12]. An Effective Microorganism is a culture of various types of beneficial microorganisms (photosynthetic bacteria, lactic acid bacteria, yeast actinomycetes, and fermentation fungi) which can increase soil microbial diversity. EM4 utilization can improve plant growth and crop yields [13].

In addition to organic liquid fertilizer, the water used for boiled and soaking soybeans can also be converted into renewable energy, namely biogas. The raw materials used are household organic waste mixed with tempeh industrial wastewater with a ratio of $1: 1$. It is because the right raw material for making biogas is comprised of 7-9\% of dry matter. Biogas technology uses microorganisms available to treat various organic waste placed in a room without air (anaerobic). Biogas can be used as a source of heat energy for cooking or as a generator for generating electricity [14]. The use of biogas energy with biogas digester has many advantages, namely reducing the effects of greenhouse gases, reducing unpleasant odors, preventing the spread of diseases, generating heat and power (mechanical/electrical), and having by-products in the forms of solid fertilizer and liquid fertilizer. This type of waste utilization is very competitive viewed from the economic perspective as fuel and inorganic fertilizer prices increase.

The type of reactor to be developed is determined by considering the environmental, economic, and social aspects. There are several types of digester, namely Floating Type, Fixed Dome Digester, and Balloon Digester Plant. Biogas for tempeh industrial wastewater that is suitable for a small-scale industry is the balloon digester plant. This type of construction is simple as it is made of plastic and installed at the ends of the inlet pipe where liquid soybean waste enters and sludge discharge pipes. In the upper part, a gas outlet pipe is installed. This type of reactor requires higher gas pressure and thus a gas pump is needed. The bag system can be used with low-pressure stoves and lamps. Advantages: low cost, flexible (easy to move), and simple construction. Disadvantage: Low gas pressure may require gas pumps and scum cannot be removed during operation [15]. The design of the balloon digester plant is shown in Fig. 3. 


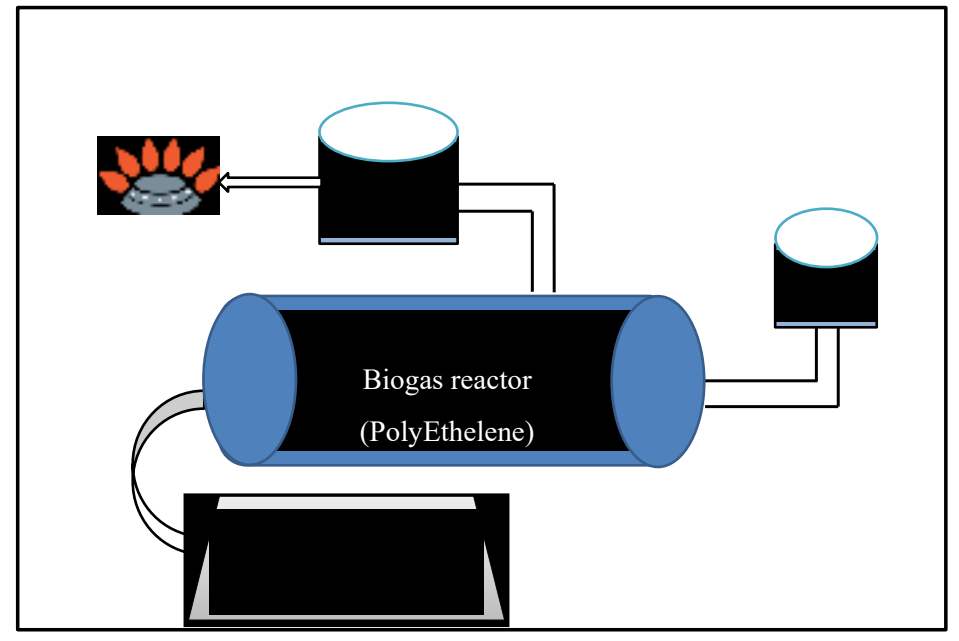

Fig. 3. Reactor design.

\subsection{Environmental aspect}

The development of MSMEs engaging in the manufacture of tempeh is proportional to the increasing amount of waste they generate. Untreated liquid tempeh industrial waste will disrupt sustainability of the the environment around those industries. Waste parameters exceeding the threshold will disrupt living creatures in the water and emit odor. If their habitat changes, the living things might not be able to live there anymore. From the environmental aspect, the proper management for wastewater from the water used for boiling and soaking is by making it liquid fertilizer and converting into biogas because it will have positive impact on the environment, including eliminating the odor produced by fermentation of waste and protecting the waters from pollution. The management of tempeh industrial waste by making it liquid fertilizer or converting it into biogas has no negative impact on the environment. The biogas sludge is converted into organic fertilizer that can be used to serve other purposes. Biogas has environmental benefits over fossil fuel or firewood. Biogas is ecological and renewable energy.

\subsection{Social aspect}

Social analysis includes acceptance by stakeholders to use their liquid waste as fertilizer and biogas. Information is required by producers through intensive counseling. This is because they assume that liquid waste can be disposed of directly without proper management. Most producers do not want to be bothered by waste management. However, by disseminating information about the impact of waste and the benefits of liquid waste, they will understand the importance of managing their waste. Moreover, the biogas development program can create employment for the surrounding community. The existence of biogas plants and the manufacture of liquid fertilizer can strengthen human resources. By transforming waste into fertilizer, they will benefit from the sale of liquid organic fertilizer

\subsection{Economic aspect}


Economic feasibility is a critical aspect in determining whether a technology is feasible or not. Economic analysis concerns considering waste management costs. The author prefers to utilize wastewater. Such utilization is undertaken by changing it into liquid organic fertilizer and biogas. The cost incurred for making liquid organic fertilizer is quite low. The estimated cost for making 120 liters of liquid organic fertilizer is IDR 150,000. The selling price of 1 liter of liquid organic fertilizer is around IDR 40,000. This means that industries will benefit from the sale of liquid organic fertilizer. Moreover, tempeh industrial waste mixed with organic household waste can also be converted into biogas. The type of biogas suitable for a small scale is the balloon digester. This type has a simple construction and low manufacturing costs, and is easy to clean and move. The costs are comprised of investment and operating costs. Investment costs include all necessary expenses used to design a biogas digester installation, namely for the purchase of materials and the manufacture of biogas installations, which are used to purchase materials and build the biogas installation amounting to IDR 1,000,000-2,000,000. The operating costs include the costs of annual maintenance of the biogas plants amounting to IDR 200,000. The balloon digester durability can reach 5 years. The costs of making tempeh using natural gas (LPG) for one month is around IDR 75,000 or IDR 900,000 for 1 year. Therefore, the use of biogas from liquid tempeh industrial waste mixed with household organic waste can help reduce fuel expenses.

\section{Conclusions}

To produce tempeh needs a lot of water for soaking, boiling, washing, and peeling the soybeans. The production of tempeh will produce a lot of wastewater containing a high organic content. The appropriate alternative waste management is to make the waste produced liquid organic fertilizer and to convert it into biogas with a mixture of household organic waste. The type of biogas suitable for a small scale is the balloon digester.

\section{Acknowledgements}

This research is funded by Universitas Indonesia's the Grant Program of Indexed International Publication for Student Final Projects (Program Hibah Publikasi Terindeks Internasional Untuk Tugas Akhir Mahasiswa/PITTA) 2018 with contract number: 2587/UN.R31/HKP.05.00/2018.

\section{References}

1. W. Shurtleff, A. Aoyagi, History of Tempeh and Tempeh Products (Soyinfo Center, USA, 2011)

2. E. Kristiningrum, D.A. Susanto, Jurnal Standardisasi 17 (2016)

3. Badan Standardisasi Nasional, Tempe: Persembahan Indonesia untuk Dunia (Jakarta, 2012)

4. P. Nurhasan, Penanganan air limbah pabrik tahu -tempe (Yayasan Bina Karya Lestari, Bintari, 1991)

5. M. Herva, A. Franco, E. F. Carrasco, E. Roca, J. Clean. Prod. 19, 1687-1699 (2011)

6. L. Čuček, J. J. Klemeš, Z. Kravanja, J. Clean. Prod. 34, 9-20 (2012)

7. A.Y. Hoekstra, T.O. Wiedmann, Science, 344, 6188, 1114-1117 (2014)

8. Z. Salamah, S.T. Wahyuni, L.B. Utami. Prosiding Seminar Nasional Penelitian (2009)

9. Murbandono, Membuat Kompos (Penebar Swadaya, Jakarta, 1990)

10. Indriani, Membuat Kompos secara Kilat (Penebar Swadaya, Jakarta, 2004) 
11. Saptoadi, Jurnal Manusia Lingkungan 8, 119-129 (2001)

12. T. Higa, G.N. Wididana, Second International Conference at Khon Kaen University, 118-124 (1994)

13. S.S. Erickson, S. Edu, H. Netti, Jurnal Teknik Kimia USU 2, 40-43 (2013)

14. I.W.R. Ardana, I.A.D. Giriantari, S.R. Hartati, LOGIC Jurnal Rancang Bangun dan Teknologi 13, 1, 49 (2017)

15. A. Kumar, B. Mandal, B., A. Sharma, Advancement in Biogas Digester. In Energy Sustainability Through Green Energy (pp. 351-382) (Springer, New Delhi, 2015) 